OPEN ACCESS

Edited by:

Luis F. Callado,

University of the Basque

Country, Spain

Reviewed by:

Kabirullah Lutfy,

Western University of Health

Sciences, USA

Angel Josabad Alonso-Castro,

Universidad de Guanajuato, Mexico

${ }^{*}$ Correspondence:

Elham A. Afify

afify001@yahoo.com

Specialty section: This article was submitted to Neuropharmacology, a section of the journal

Frontiers in Neurology

Received: 06 December 2016 Accepted: 15 February 2017

Published: 02 March 2017

Citation:

Afify EA, Alkreathy HM, Ali AS, Alfaifi HA and Khan LM (2017)

Characterization of the

Antinociceptive Mechanisms of Khat Extract (Catha edulis) in Mice.

Front. Neurol. 8:69.

doi: 10.3389/fneur.2017.00069

\section{Characterization of the Antinociceptive Mechanisms of Khat Extract (Catha edulis) in Mice}

\author{
Elham A. Afify ${ }^{1,2 *}$, Huda M. Alkreathy ${ }^{3}$, Ahmed S. Ali ${ }^{3}$, Hassan A. Alfaifi ${ }^{3}$ and Lateef M. Khan ${ }^{3}$ \\ ${ }^{1}$ Faculty of Pharmacy, Alexandria University, Alexandria, Egypt, ${ }^{2}$ Department of Pharmacology and Toxicology, Faculty of \\ Pharmacy, King Abdulaziz University, Jeddah, Saudi Arabia, ${ }^{3}$ Faculty of Medicine, Department of Pharmacology, King \\ Abdulaziz University, Jeddah, Saudi Arabia
}

This study investigated the antinociceptive mechanisms of khat extract $(100,200$, and $400 \mathrm{mg} / \mathrm{kg}$, i.p.) in four pain models: two thermic (hot plate, tail-flick) and two chemical (acetic acid, formalin) models. Male mice were pretreated intraperitoneally (i.p.) with the opioid receptor blocker naloxone (5 mg/ $\mathrm{kg}$ ), the cholinergic antagonist atropine (2 mg/ $\mathrm{kg}$ ), the selective $\alpha_{1}$ blocker prazosin (1 mg/kg), the dopamine $D_{2}$ antagonist haloperidol $(1.5 \mathrm{mg} / \mathrm{kg})$, or the $\mathrm{GABA}_{\mathrm{A}}$ receptor antagonist, bicuculline $(1 \mathrm{mg} / \mathrm{kg}) 15$ minutes prior to i.p. injection of khat extract $(400 \mathrm{mg} / \mathrm{kg}$ ). Khat extract reduced the nociceptive response of mice in the four pain tests. Naloxone significantly inhibited the antinociceptive effect of khat extract in the hot plate, tail-flick, and the first phase of formalin tests. Bicuculline significantly antagonized the antinociceptive effect of khat extract on the hot plate and tail-flick tests. Haloperidol significantly reversed the antinociceptive effect of khat extract on the tail-flick test and the first phase of formalin test. These results provide strong evidence that the antinociceptive activity of khat extract is mediated via opioidergic, GABAergic, and dopaminergic pathways. The mechanism of the antinociceptive action of khat may be linked to the different types of pain generated in animal models.

Keywords: khat (Catha edulis), hot plate, formalin, tail flick, opioidergic, dopaminergic, GABAergic

\section{INTRODUCTION}

Pain is a common reason to seek medical consultation due to its high prevalence (1). Both shortterm and chronic use of most of the current pain medications such as NSAIDs and opioids is associated with many adverse effects and potential interactions with other medications (2). This explains the increasing interest in the use of herbal medicine as an alternative or adjuvant for classic analgesics (3). Khat (Catha edulis) is a medium-sized evergreen tree of psychostimulant nature that is cultivated in Yemen and East African countries (4). Chewing of khat leaves is a traditional habit in different populations to alleviate fatigue and produce analgesia (5-7). Detailed description of chemical and pharmacological profile and negative health impact of khat abuse were documented and critically reviewed $(8,9)$.

Among 20 psychoactive substances, khat is considered as the least harmful herb of low dependence potential (10). The major active constituents of khat extract include six major alkaloids, tannins, and flavonoids (11). The WHO recommended that the potential for abuse and dependence of khat and its constituents is low and that its impact on public health do not warrant international control (12). Moreover, khat has some positive characteristics, which 
encourage its further studies. These effects include lowering of plasma cholesterol and reduction in glucose and triglycerides concentration (13) in addition to its potent cytotoxicity and antibacterial activity (14). These effects are predominantly due to cathinone, the main psychoactive component in khat. Interestingly, the use of khat could be beneficial in pain management due to the poor abuse liability of the active constituents. Earlier studies have demonstrated prolonged analgesic effect induced by cathinone (15) and khat in animal models $(16,17)$. Both opiate (16) and non-opiate (15, 18) pathways have been suggested as a mechanism for the antinociceptive action of khat. However, the identification of the exact receptors mediating the antinociceptive action of khat is not investigated.

The process of pain is a complex phenomenon that is connected to the type of the painful stimulus, the type of nerves involved in pain transmission, and the neurotransmitters released (19). The link between the antinociceptive effect of khat and the type of pain elicited by the nociceptive signal has not been addressed. Different nociceptive stimuli including thermal, chemical, and inflammatory signals activate specific types of nerve fibers, namely, $\mathrm{A} \delta$ and $\mathrm{C}$ fibers $(20,21)$. The difference in the mechanism of action of analgesic agents as opioids based on the pain test has been documented (22). Although numerous studies have investigated the antinociceptive effect of cathinone, only few studies have dealt with the effects of whole material, as normally taken by users and none of these studies addressed the link between the antinociceptive effect of khat and the type of painful stimulus and if there is a direct evidence of the involvement of different neurotransmitters in the antinociceptive action of khat following acute administration. In this study, we investigated the antinociceptive mechanisms of khat extract in relation to the type of pain tested. Two chemical pain tests, acetic acid-induced writhing and formalin-induced licking in addition to two thermal models, hot plate and tail-flick tests were performed on mice. The involvement of different receptors in the antinociceptive action of khat was also investigated using the opioid antagonist naloxone, the cholinergic antagonist atropine, the selective $\alpha_{1}$ blocker prazosin, the dopamine $\mathrm{D}_{2}$ antagonist haloperidol, and the $\mathrm{GABA}_{\mathrm{A}}$ receptor antagonist, bicuculline.

\section{MATERIALS AND METHODS}

\section{Animals}

Male Swiss mice (30-40 g) from King Fahd Medical Research Center, King Abdulaziz University, Jeddah, Saudi Arabia were used in the present study. The mice were kept in cages under standardized conditions with $12 / 12 \mathrm{~h}$ light/dark cycle in a temperature-controlled room at $22 \pm 2^{\circ} \mathrm{C}$ with free access to food and water. The study was performed according to the institutional recommendations for the care and use of experimental animals of the research and ethics committee, ethical approval No. $109 / 1438 / \mathrm{BR}$. The protocol was approved by the research ethical committee, substance of abuse research center. All animals were used only for one procedure and were humanely sacrificed under anesthesia after the completion of experiment. The experiments were performed by an observer blind to the treatment type.

\section{Drugs}

Morphine sulfate, diclofenac sodium, and haloperidol were from Jamjoom Pharma Factory (Jeddah, KSA). Bicuculline and atropine sulfate were from Sigma Chemical Co. (St. Louis, MO, USA). Prazosin and naloxone were from Tabuk Pharmaceuticals Manufacturing Company (Kingdom of Saudi Arabia). Atropine sulfate, morphine, and naloxone were dissolved in saline. Bicuculline was dissolved in normal saline with few drops of concentrated acetic acid 97\% (23). Haloperidol ampoule (5 mg/ $\mathrm{mL}$ ) was diluted in saline.

\section{Preparation of Khat Extract}

A total of $300 \mathrm{~g}$ of fresh plants of C. edulis (stem tips and leaves) were provided by Substance Abuse Research Center (Jizan University). The transported fresh packed bundles were carried on the same day in an ice box to the laboratory and stored at $-20^{\circ} \mathrm{C}$ overnight. The dried plants were washed with distilled water to remove dust and debris and dried in freeze dryer for two nights. The dried leaves (weighed $88 \mathrm{~g}$ ) were crushed with pestle in a mortar and immersed with ethanol $96 \%$ in a flask (24). The mixture of khat material and ethanol was stirred gently and then left to stand overnight wrapped with aluminum foil to avoid light-induced decomposition. The content was later filtered, first by use of gauze roll to separate the big particles followed by filter paper to remove the fine particles (25). The filtrate was evaporated under rotary pump to remove ethanol then, in a vacuum at $40^{\circ} \mathrm{C}$ to remove all traces of ethanol. The resulting ethanol-free extract ( $12 \mathrm{~g}$ ) constituted $4 \%$ of the original fresh material (26). Extracts were stored in refrigerator after wrapping in parafilm. The batch of $300 \mathrm{~g}$ of fresh leaves bundles produced $12 \mathrm{~g}$ of dry extract representing 100:4 leaf-to-extract extraction ratio. Khat extract was freshly dissolved in normal saline and kept in refrigerator at $4^{\circ} \mathrm{C}$ prior to use. The identity of the active constituents was confirmed by mass spectroscopy and showed that both cathinone and cathine existed in approximately equal concentration.

\section{Mass Spectra}

A weight of $20 \mathrm{mg}$ of sample powder was extracted by $5 \mathrm{~mL}$ of methanol, filtered through $0.45 \mu \mathrm{m}$ nylon filter, dried with nitrogen gas, and the residue was reconstituted in $50 \mu \mathrm{L}$ methanol. A volume of $5 \mu \mathrm{L}$ was injected for LC-MS analysis (Agilant 6300 Ion trap, USA) applying positive-Auto-MSn mode. A representative MS chromatogram (extracted ion chromatogram) showed cathinone $\mathrm{m} / \mathrm{z} 134$ at $6.6 \mathrm{~min}$ and cathine $\mathrm{m} / \mathrm{z} 132$ at $7.5 \mathrm{~min}$ (Figure 1). The average MS spectra were confirmed by NIST2008 database.

\section{Experimental Groups and Protocols Animal Testing} Acetic Acid-Induced Abdominal Writhing

The experimental groups of mice $(n=6)$ were treated with khat extract (i.p.) $30 \mathrm{~min}$ before the administration of $0.6 \%$ acetic acid solution $(10 \mathrm{~mL} / \mathrm{kg}$, i.p.). Injection of acetic acid in 


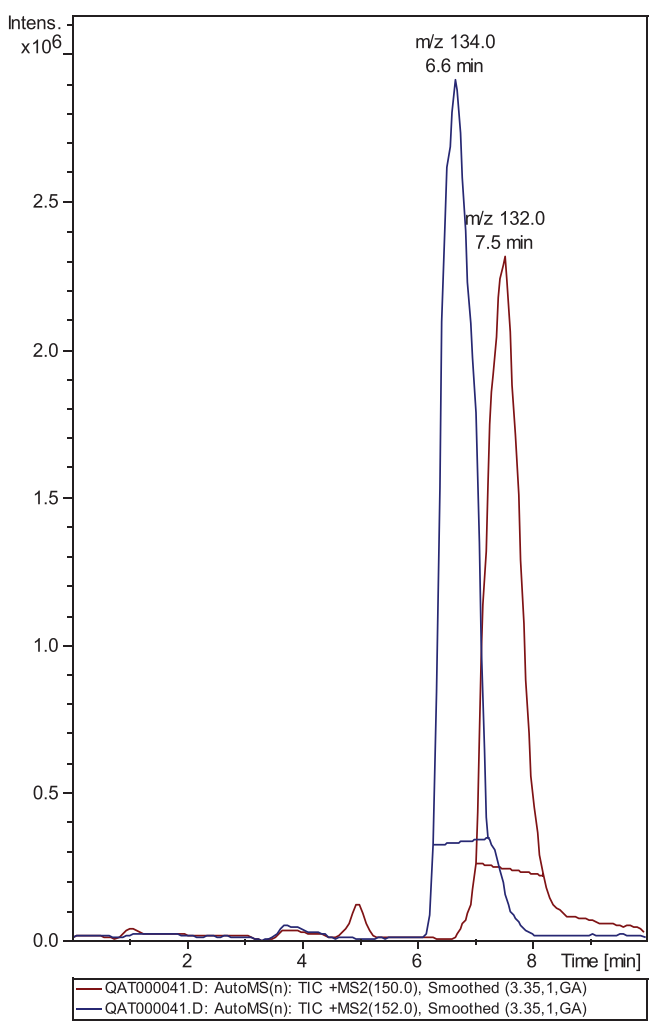

Zoomed $=\mathrm{MS} / \mathrm{MS}$ of Cathinone $[\mathrm{M}+\mathrm{H}]^{+}=m / z 150$
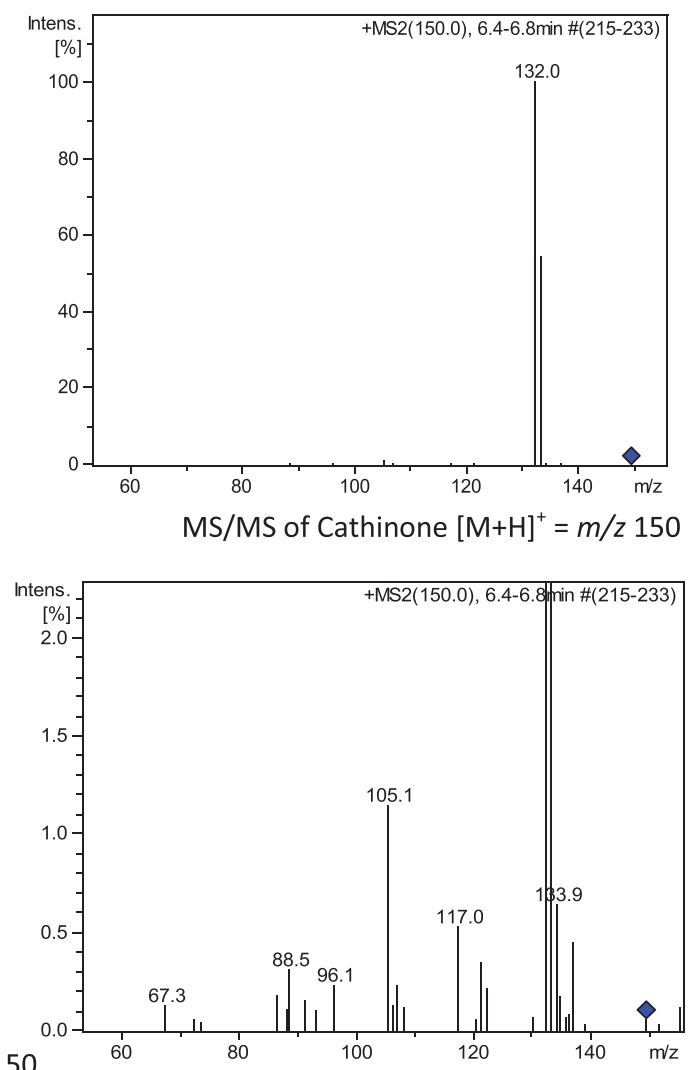

FIGURE 1 | MS/MS chromatogram (MS2) of $\mathbf{m} / \mathbf{z} 150(\rightarrow$ 132) and $152(\rightarrow$ 134). Cathine, at 6.6 min; cathinone at 7.5 min

mice showed characteristic abdominal constrictions in the form of muscle contraction joined with hind limb stretching (27). The nociception intensity was quantified by counting the total number of writhings within $30 \mathrm{~min}$ after acetic acid injection.

\section{Formalin-Induced Pain}

The animals were treated with $50 \mu \mathrm{L}$ of $1 \%$ formalin in region of the right hind paw. Following formalin injection, the mouse injected paw was observed for $30 \mathrm{~min}$ in an acrylic box. The time for licking the paw was observed in two phases, $0-5 \mathrm{~min}$ (neurogenic pain), and 15-30 min (inflammatory pain) (28).

\section{Hot Plate Test}

Each mouse was placed on a metallic surface of the hot plate (Ugo Basile Comerio, Italy) kept at $50 \pm 1^{\circ} \mathrm{C}$. After $30 \mathrm{~min}$ of injections of the animals, the latency in seconds was recorded using stop watch as the time between adjusting the animal on the hot plate and the appearance of symptoms of discomfort as licking of the hind paws, shaking, or jumping off from the surface. The cutoff time of $60 \mathrm{~s}$ was selected according to Woolfe and MacDonald (29).

\section{Tail-Flick Test}

A radiant heat analgesiometer (Ugo Basile Tail Flick Apparatus, Comerio, Italy) was used as described by D’Amour and
Smith (30). The light beam was focused on the mouse's tail from above after wrapping the animal gently in a cotton towel. The recorded response was a tail flick away from a light source. A stopwatch was used to measure the reaction time to the nearest second. The intensity of radiant heat was adjusted to yield the baseline latencies of 6-8 s. Under the current experimental conditions, the cutoff time was $15 \mathrm{~s}$. This long cutoff time was imposed to reduce the intensity of the stimulus as a protection against tissue damage since the test was repeated every $10 \mathrm{~min}$ as reported earlier by Connor et al. (17). Each mouse was tested twice, before drug or vehicle administration and 10, 20, and 30 min thereafter.

\section{Effect of Khat Extract on Pain Perception in Pain Models}

For each pain test, a total of five groups of male mice $(n=6-8)$ was used and received the following treatments, group I: vehicle (saline) served as control. The second, third, and fourth groups were treated with three doses of khat extract, 100, 200, and $400 \mathrm{mg} / \mathrm{kg}$ i.p., respectively. The fifth group (positive control) injected with morphine $(1 \mathrm{mg} / \mathrm{kg}$, i.p.) in case of hot plate and tail-flick tests or diclofenac sodium $(20 \mathrm{mg} / \mathrm{kg}$, i.p. $)$ in case of formalin test and acetic acid-induced writhing. In pilot experiments, lower doses of khat extract 25 and $50 \mathrm{mg} / \mathrm{kg}$ are used. Only $50 \mathrm{mg} / \mathrm{kg}$ produced slight inhibition in the acetic acid-induced 
writhing. These lower doses levels were also tested in other behavioral tests performed as locomotion and sedative activity and found to be ineffective. Therefore, we selected three dose levels to perform the antinociception experiments based on trials and on a previously published study (31), as well as considering the estimated amount of khat weight administered by chewers and the yield of khat extract. The responses were recorded for $30 \mathrm{~min}$ after khat treatment according to the test performed as previously mentioned under Section "Experimental Groups and Protocols." The use of positive control either morphine or diclofenac was based on the mechanism of the pain test. For testing the mechanisms of analgesia as in acetic acid-induced writhing and formalin test, diclofenac is used. Morphine is used as a positive control to test analgesia due to inhibition of centrally transmitted pain as in the tail-flick test and hot plate test. The time was fixed for $30 \mathrm{~min}$ in all pain tests for the comparative purposes and to minimize pain sensation in animals from repeated exposure to painful stimuli as heat. Similar time protocol was previously utilized (17).

\section{Characterization of Antinociceptive Mechanisms of Khat Extract}

Experiments were designed to elucidate possible mechanisms by which khat extract induced antinociception in mice in the four pain models. For each pain test, mice were divided into seven groups. Since the $400 \mathrm{mg} / \mathrm{kg}$ dose of khat extract produced maximal antinociceptive effect in the four pain models, we decided to test this dose further to study the mechanism of action of khat. Group I: (control) received equal volumes of saline. Group II: khat extract (400 mg/kg, i.p.), Group III: opioid receptor antagonist naloxone (5 mg/kg, i.p.), Group IV: the cholinergic antagonist atropine $\left(2 \mathrm{mg} / \mathrm{kg}\right.$, i.p.), Group V: the selective $\alpha_{1}$ blocker prazosin (1 mg/kg, i.p.), Group VI: the dopamine $\mathrm{D}_{2}$ antagonist haloperidol (1.5 $\mathrm{mg} / \mathrm{kg}$, i.p.), and Group VII: the $\mathrm{GABA}_{\mathrm{A}}$ receptor antagonist, bicuculline $(1 \mathrm{mg} / \mathrm{kg}$, i.p.). The doses of the blockers used were based on pilot experiments and literature review (32) to block the receptors. These doses are used in the four pain tests and are kept constant for the comparative purposes. All blockers treatment were done $15 \mathrm{~min}$ prior to i.p. administration of $400 \mathrm{mg} / \mathrm{kg}$ khat extract (Groups III-VII). According to the test performed, the response related to the pain test was measured for $30 \mathrm{~min}$ after khat treatment as previously described under Section "Experimental Groups and Protocols."

\section{Statistical Analysis}

Results are presented as mean \pm SEM for each experimental group. Statistical comparison of the data was performed by oneway analysis of variance followed by Bonferroni's post hoc test using the GraphPad Prism software (version 5.0) for Windows. The level of significance was set at $P<0.05$.

\section{RESULTS}

\section{Khat Extract Produced Antinociception in All Models of Pain Hot Plate Test}

Treatment of mice with khat extract for 30 min significantly increased the latency only with $400 \mathrm{mg} / \mathrm{kg}$ of khat extract compared to the control value of $17.75 \pm 0.95 \mathrm{~s}$. The positive control morphine $(1 \mathrm{mg} / \mathrm{kg}$ i.p.) produced a significant change in the latency $37.33 \pm 1.42$ (Figure 2 ).

\section{Tail-Flick Test}

Compared with the control mice, i.p., administration of khat extract (200 and $400 \mathrm{mg} / \mathrm{kg}$ ) resulted in a significant enhancement of the tail-flick latency. The antinociceptive effect of the intermediate and high doses of khat extract was superior than $1 \mathrm{mg} / \mathrm{kg}$, i.p. morphine. Khat extract (400 mg/kg, i.p.) seemed to be most active; the peak was achieved at $10 \mathrm{~min}(10.48 \pm 0.87 \mathrm{vs}$. $6.41 \pm 0.70 \mathrm{~min})$, time to tail flick was doubled at $30 \mathrm{~min}$ postinjection $(9.41 \pm 0.67$ vs. $4.87 \pm 0.31 \mathrm{~min})$. Transforming data to area under curve scores indicated dose-dependent antionciceptive effect of khat extract (Figure 3).

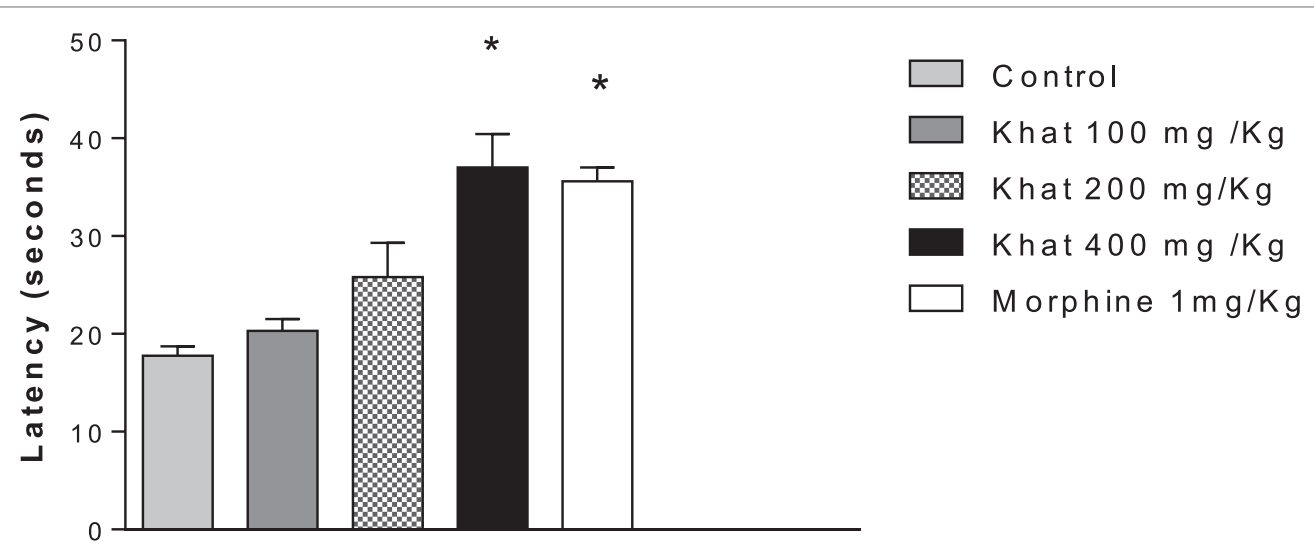

FIGURE 2 | Effect of khat extract (100, 200, and $400 \mathrm{mg} / \mathrm{kg}$ ip.), morphine (1 mg/kg ip.) on the nociceptive response of mice in the hot plate. Values are mean \pm SEM of the latency for the nociceptive behavior (seconds) $(n=6-8)$. Significantly different from control group at ${ }^{*} P<0.05(F$ value $=10.991$, ANOVA followed by Bonferroni's post hoc test). 

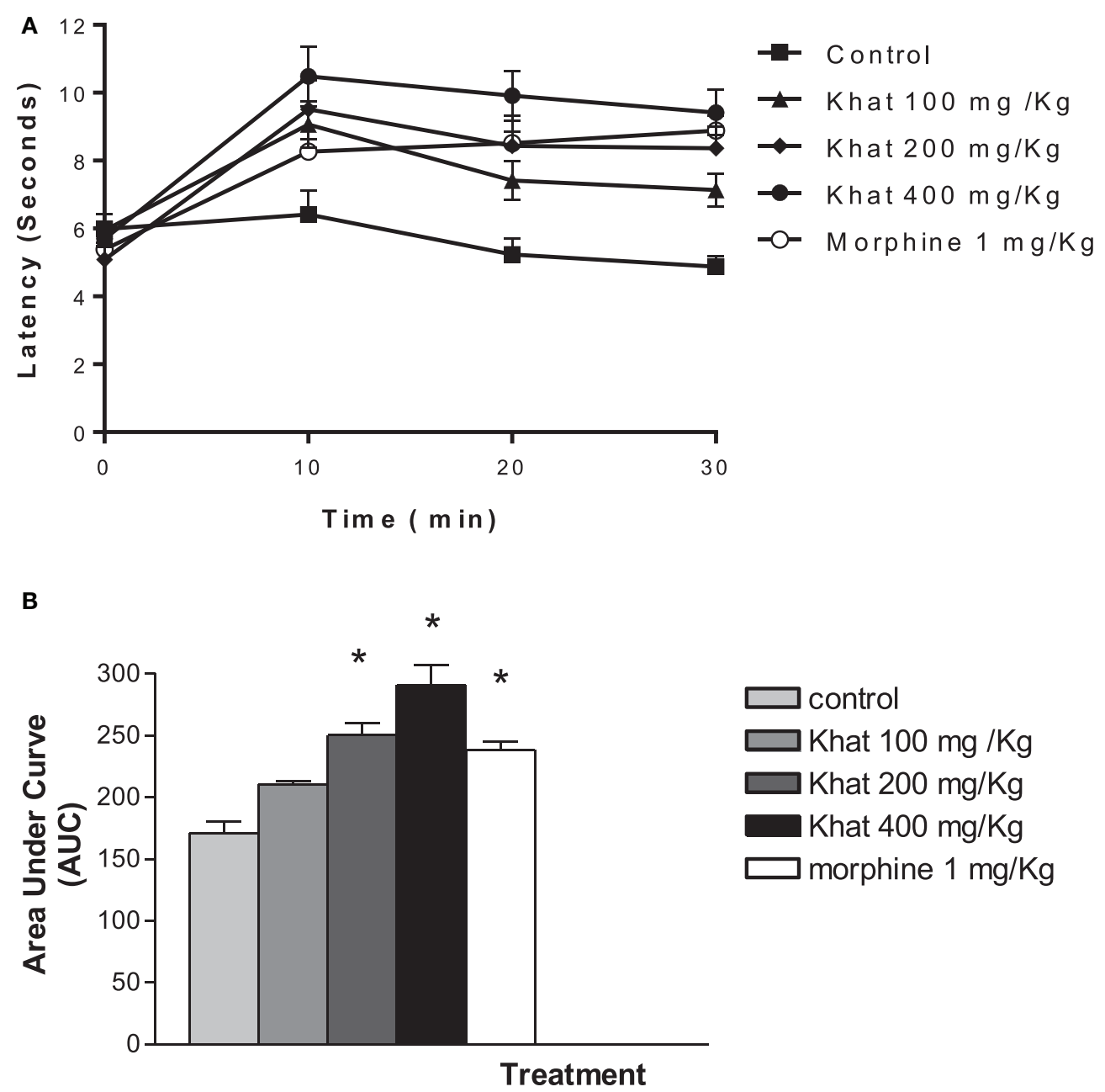

FIGURE 3 | Time course of khat extract (100, 200, and $\mathbf{4 0 0} \mathbf{~ m g / k g ~ i . p . ) ~ a n d ~ m o r p h i n e ~ ( 1 ~} \mathbf{~ m g / k g}$, ip) in the mouse tail-flick test (A). The lower panel (B) shows the area under curve (AUC) from 0 to $30 \mathrm{~min}$. Values are mean $\pm \mathrm{SEM}(n=6-8)$. Significantly different from control group at ${ }^{\star} P<0.05(F$ value $=46.997$, ANOVA followed by Bonferroni's post hoc test).

\section{Acetic Acid-Induced Abdominal Writhing}

The injection of $0.6 \%$ acetic acid solution $(0.1 \mathrm{~mL} / 10 \mathrm{~g})$ to mice induced a characteristic writhing response between 0 and 30 min later, which was significantly $(P<0.05)$ inhibited by pretreatment with diclofenac $(20 \mathrm{mg} / \mathrm{kg})$. Khat extract $(100$, 200 , and $400 \mathrm{mg} / \mathrm{kg}$, i.p.) injected $30 \mathrm{~min}$ prior to the stimulus injection caused dose-dependent inhibition of the abdominal constrictions $(59.7-78.9 \% ; P<0.05)$ compared with the control group (Figure 4 ). The positive control group produced $92 \%$ inhibition.

\section{Formalin test}

Treatment of animals with khat extract (100, 200, and $400 \mathrm{mg} /$ $\mathrm{kg}$, i.p.) or diclofenac $20 \mathrm{mg} / \mathrm{kg}$ i.p. reduced the licking time of hind paw by $61.8,75,89.2$, and $3.6 \%$, respectively, in the first phase $(0-5 \mathrm{~min})$ vs. control value of $189.5 \pm 10.89 \mathrm{~s}$. In the inflammatory phase (15-30 min), treatment with khat extract
(100, 200, and $400 \mathrm{mg} / \mathrm{kg}$, i.p.) or diclofenac $20 \mathrm{mg} / \mathrm{kg}$ i.p. reduced the licking time by $90,92.4,96.6$, and $74.3 \%$, respectively, from a control value of $265.12 \pm 13.12 \mathrm{~s}$ (Figures 5A,B).

\section{Naloxone, Bicuculline, and Haloperidol Antagonized the Antinociceptive Effect of Khat Extract}

None of the blockers tested changed the nociceptive response of mice in the four animal models or produced analgesia per se compared to the control group (data are not shown). Khat extract (400 mg/kg, i.p.) significantly increased the pain latency in the hot plate test. The nociceptive threshold was increased by 2.2 -fold compared to the control value, $37 \pm 3.43$ vs. $17.75 \pm 0.95 \mathrm{~s}$, respectively. The antinociceptive effect of khat extract was reversed by prior administration of the opioid receptor antagonist naloxone and the $\mathrm{GABA}_{\mathrm{A}}$ antagonist bicuculine but unaffected by the centrally acting dopamine $\mathrm{D}_{2}$-receptor antagonist, haloperidol, the $\alpha_{1}$ 


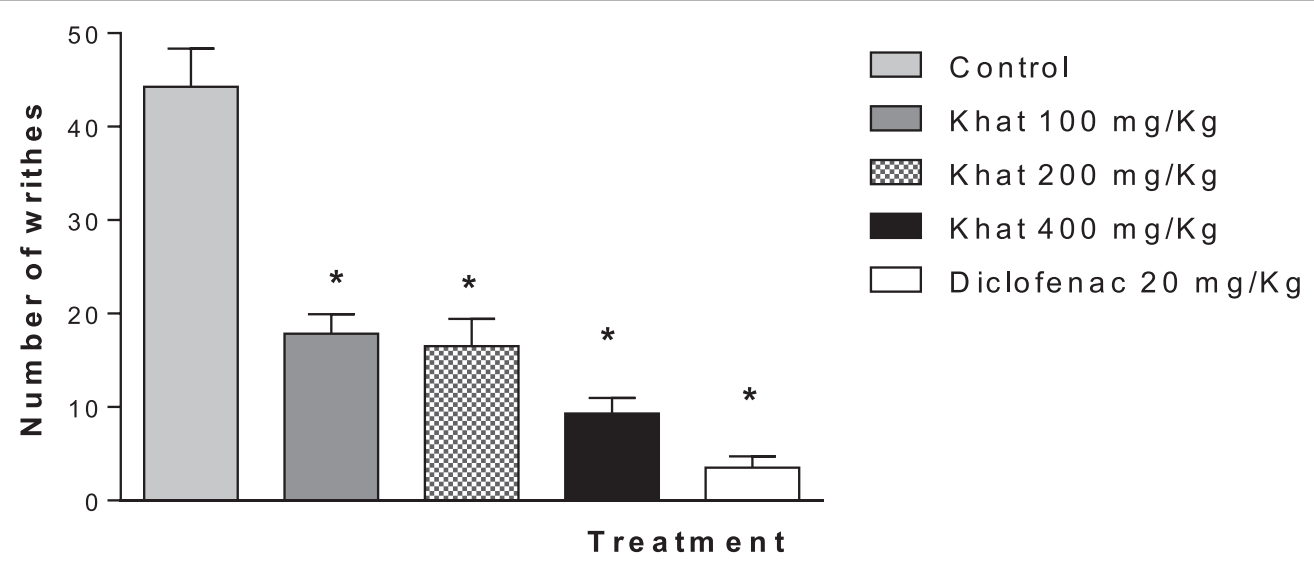

FIGURE 4 | Effect of khat extract (100, 200, and $\mathbf{4 0 0 ~} \mathbf{~ m g / k g ~ i . p . ) ~ o n ~ t h e ~ n u m b e r ~ o f ~ a c e t i c ~ a c i d - i n d u c e d ~ w r i t h e s ~ i n ~ m i c e . ~ D i c l o f e n a c ~ ( 2 0 ~ m g / k g ~ i . p . ) ~ w a s ~}$ used as positive control. Values are mean of cumulated writhings in $30 \mathrm{~min} \pm \mathrm{SEM}(n=6-8)$. Significantly different from control group at ${ }^{*} P<0.05(F$ value $=35.16$, ANOVA followed by Bonferroni's post hoc test).
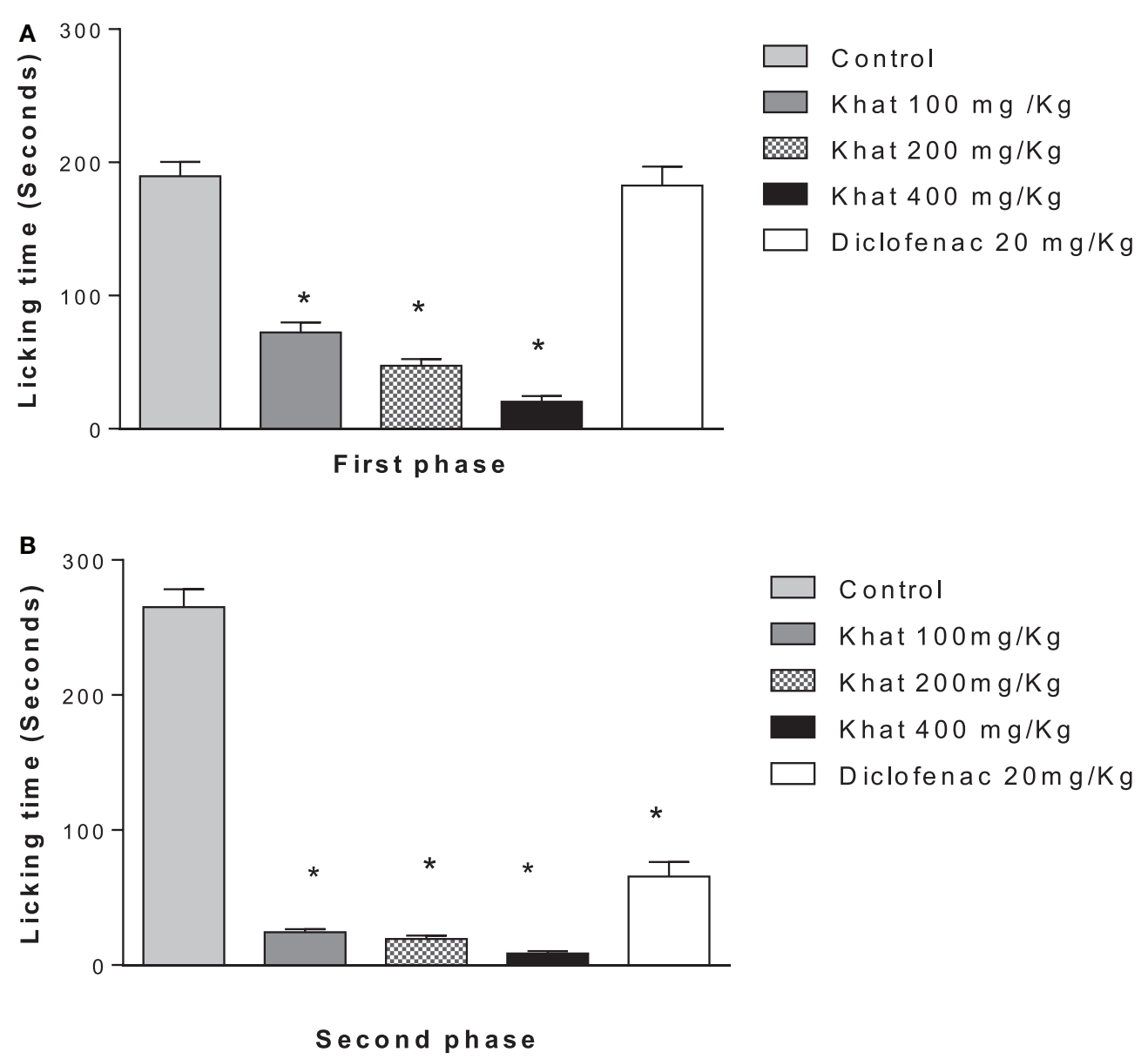

FIGURE 5 | Effect khat extract (100, 200, and $400 \mathrm{mg} / \mathrm{kg}$ i.p.), diclofenac (20 $\mathrm{mg} / \mathrm{kg}$ i.p.) on the licking time in seconds of formalin-induced pain in mice, in the first phase (A) (0-5 $\mathbf{~}$ in), $\boldsymbol{F}$ value $=\mathbf{7 0 . 0 3 0}$ and the second phase (B) (15-30 $\mathbf{m i n})$. Values are mean \pm SEM $(n=6-8)$. Significantly different from control group at ${ }^{*} P<0.05$ ( $F$ value $=170.87$, ANOVA followed by Bonferroni's post hoc test). 
blocker prazosin or the cholinergic blocker atropine (Figure 6). In the tail-flick test, prior administration of naloxone, bicuculline, or haloperidol inhibited the antinociceptive effect of khat extract (Figure 7). On the other hand, the antinociceptive effect of khat extract was reversed by prior administration of naloxone or haloperidol during the first phase of formalin test (Figure 8A). None of the blockers tested significantly changed the licking time during the second phase of formalin test (Figure 8B) or the number of writhes induced by acetic acid administration (Figure 9).

\section{DISCUSSION}

In this study, khat extract markedly increased the pain response in two thermally induced pain models, namely, the hot plate and tail-flick tests and inhibited the chemically generated writhing and licking responses induced by acetic acid and formalin injection, respectively. The opioidergic, GABAergic, and dopaminergic receptors but not the adrenergic or muscarinic ones are involved in the antinociceptive action of khat. The opioidergic and dopaminergic mechanisms are involved in the antinociceptive action of khat probably involving A $\delta$ fibers. This is the first study to link the antinociceptive action of khat to particular pain fibers. Khat extract and its constituent cathinone have been shown to have analgesic properties in similar pain tests $(17,33,34)$. In addition, cathine (Norpseudoephedrine), a metabolite of cathinone enhanced the analgesic effects of morphine in hot plate and formalin tests in mice (34). Thus, our results confirmed previous reports

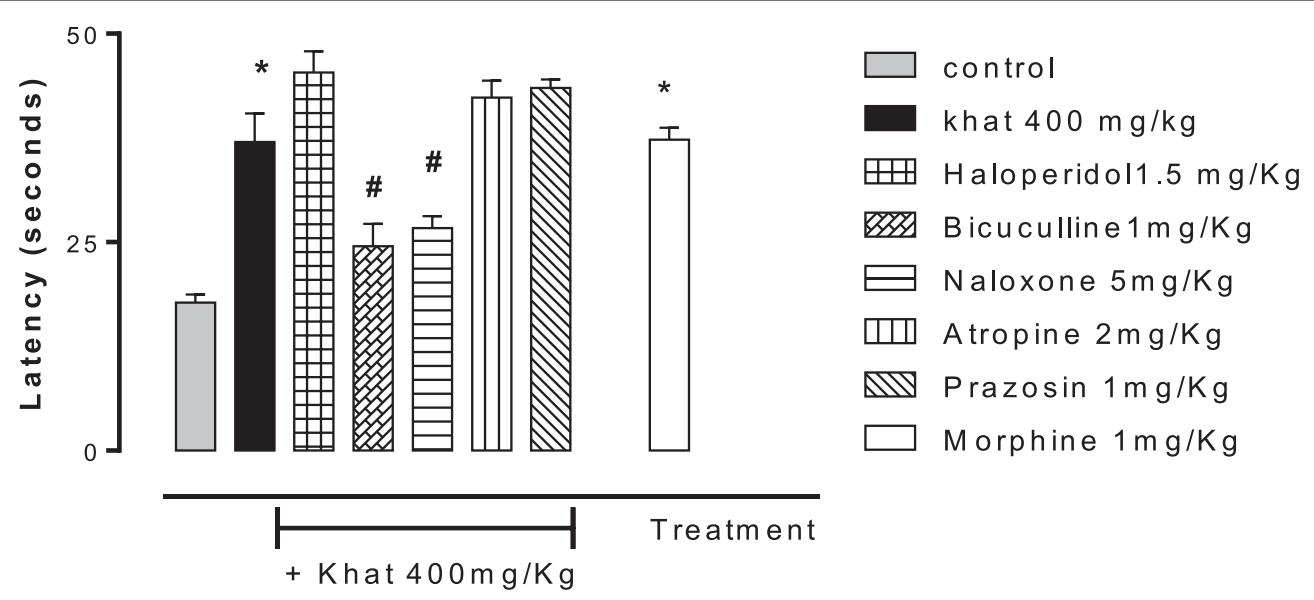

FIGURE 6 | Effect of haloperidol (1.5 mg/kg, i.p.), bicuculline (1 mg/kg, i.p.), naloxone (5 mg/kg, i.p.), atropine (2 mg/kg, i.p.), and prazosin (1 mg/kg, i.p.) on antinociception induced by khat extract $\mathbf{( 4 0 0} \mathbf{~} \mathbf{~ g} \mathbf{~} \mathbf{k g}$, i.p.) on the hot plate latency in mice. Drugs or saline (control) were administered 15 min prior to khat extract. Values are mean \pm SEM $(n=6-8)$. Significantly different from control group at ${ }^{\star} P<0.05$. Significantly different from khat group at ${ }^{\#} P<0.05$ ( $F$ value $=28.594$, ANOVA followed by Bonferroni's post hoc test).

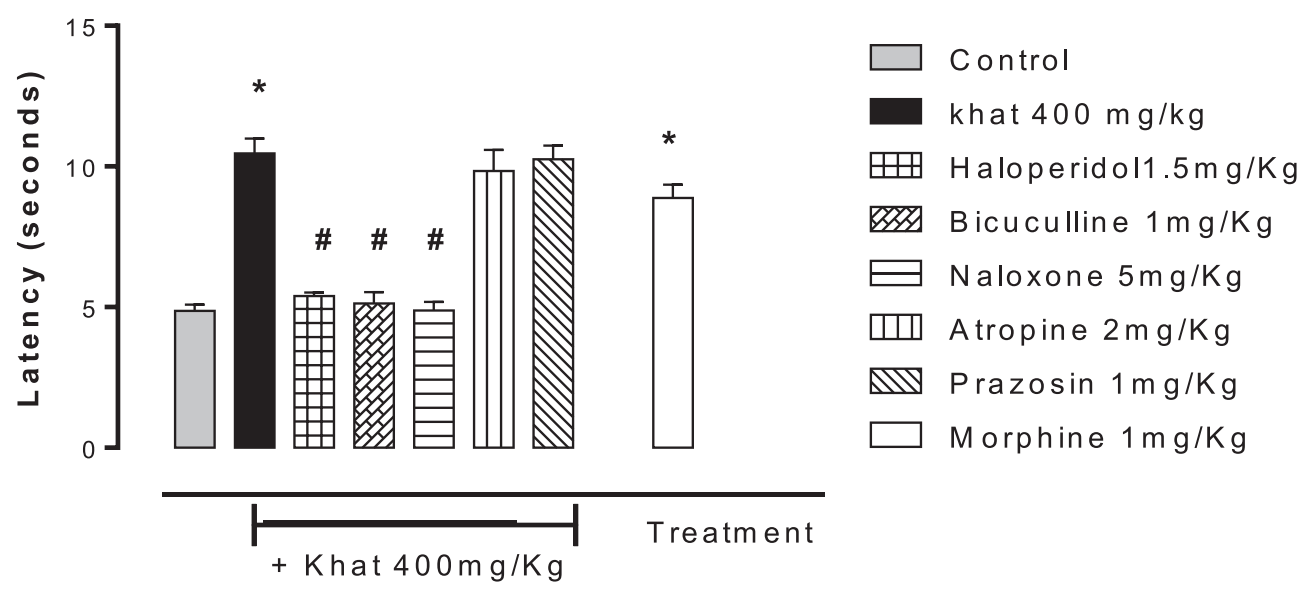

FIGURE 7 | Effect of haloperidol (1.5 mg/kg, i.p.), bicuculline (1 mg/kg, i.p.), naloxone (5 mg/kg, i.p.), atropine (2 mg/kg, i.p.), and prazosin (1 mg/kg, i.p.) on antinociception caused by khat extract $\mathbf{( 4 0 0} \mathbf{~ m g / k g}$, i.p.) on the tail-flick test in mice. Drugs or saline (control) were administered 15 min prior to khat extract. Values are mean \pm SEM $(n=5-8)$. Significantly different from control group at ${ }^{*}<0.05$. Significantly different from khat group at ${ }^{\prime} P<0.05$ ( $F$ value $=32.140$, ANOVA followed by Bonferroni's post hoc test). 
A

Formalin test (First Phase)

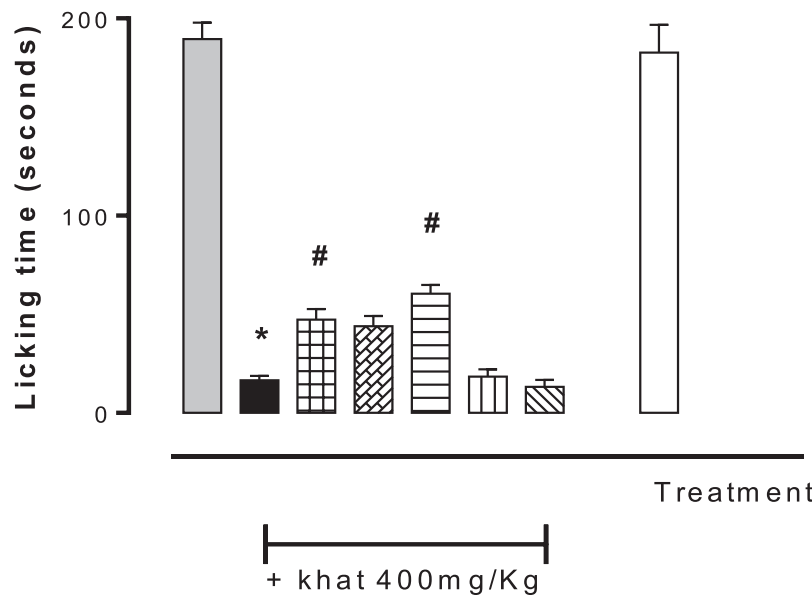

B

Formalin test (Second Phase)

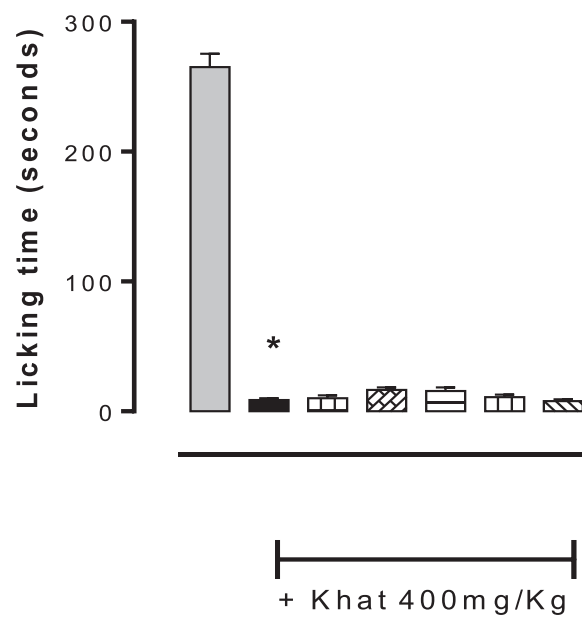

FIGURE 8 | Effect of haloperidol (1.5 mg/kg, i.p.), bicuculline (1 mg/kg, i.p.), naloxone (5 mg/kg, i.p.), atropine (2 mg/kg, i.p.), prazosin (1 mg/kg, i.p.) on antinociception induced by khat extract $(400 \mathrm{mg} / \mathrm{kg}$, i.p.) on the licking time of formalin-induced pain in mice, in the first phase (A) (0-5 min) $\boldsymbol{F}$ value $=\mathbf{9 6 . 0 5 9}$ and the second phase $(\mathbf{B})$ (15-30 $\mathbf{~ m i n})$. Drugs or saline (control) were administered 15 min prior to khat extract. Values are mean \pm SEM $(n=5-8)$. Significantly different from control group at ${ }^{\star} P<0.05$. Significantly different from khat group at ${ }^{\#} P<0.05$ ( $F$ value $=196.87$, ANOVA followed by Bonferroni's post hoc test).

that khat extract attenuated pain signals generated by different painful stimuli.

The present results demonstrated that the opioid antagonist, naloxone, attenuated the antinocieptive response of khat extract in hot plate, tail-flick, and first phase of formalin tests. This is in agreement with previous results $(18,33,34)$ reported that cathinone-induced analgesia was antagonized by naloxone pretreatment. In contrast, our results indicated that naloxone pretreatment has no effect on the analgesic effect of khat in mice challenged with acetic acid and during the second phase of formalin test. The biphasic action of formalin has different nociceptive pathways. The first phase (neurogenic) is detected by central nociceptive afferent terminals stimulating the A $\delta$ fibers. The second phase is an inflammatory response due to direct stimulation of chemical nociceptors resulting in an increased input from C fibers (28). Similarly, visceral pain induced by acetic acid is perceived via C fibers (27). The painful thermic stimuli in hot plate and tail-flick tests are also involving stimulation of the A $\delta$ fibers. It has been shown that the opioid antagonists naloxonazine and naltriben differently attenuated antinociception involving $\mathrm{C}$ fibers compared with A $\delta$ fiber-mediated response (35). Thus, it is conceivable that naloxone inhibited the analgesic effect of khat extract in pain tests mediated via A $\delta$ fibers, namely, hot plate, tail-flick, and 


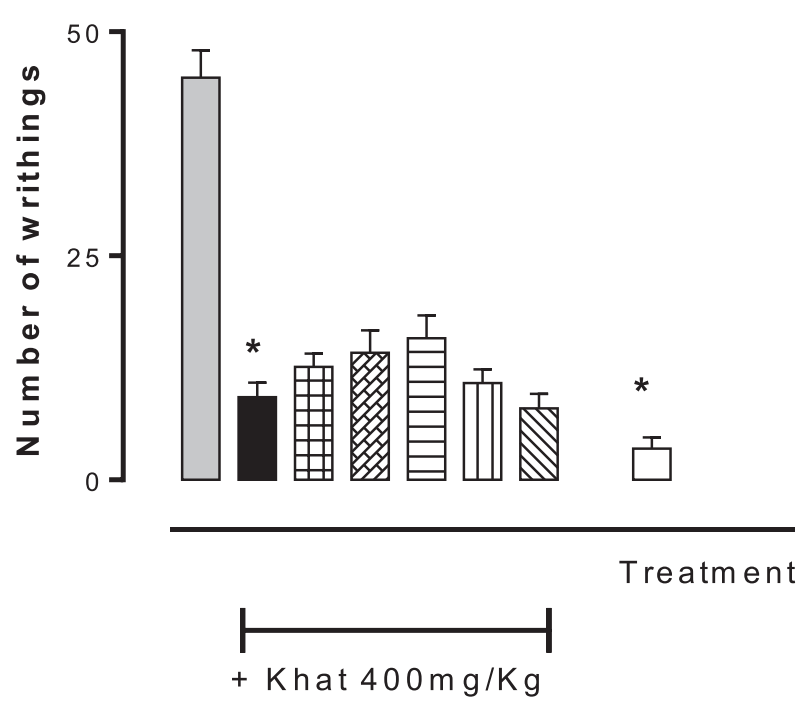

FIGURE 9 | Effect of haloperidol (1.5 mg/kg, i.p.), bicuculline (1 mg/kg, i.p.), naloxone (5 mg/kg, i.p.), atropine (2 mg/kg, i.p.), and prazosin (1 mg/kg, i.p.) on antinociception induced by khat extract $(\mathbf{4 0 0} \mathbf{~ m g} / \mathbf{k g}$, i.p.) in acetic acid-induced writhing in mice. Drugs or saline (control) were administered 15 min prior to khat extract. Values are mean \pm SEM $(n=5-8)$. Significantly different from control group at ${ }^{\star} P<0.05$. Significantly different from khat group at ${ }^{\#} P<0.05$ ( $F$ value $=44.136$, ANOVA followed by Bonferroni's post hoc test)

first phase of formalin test but not those activating the $\mathrm{C}$ fibers as second phase of formalin test and acetic acid-induced writhing. The differential antinociceptive effect for analgesic agents according to the painful stimulus was reported earlier for khat (17), morphine $(22,36)$, and for other centrally acting drugs such as amphetamine (18) and nicotine (37). Taken together, the opioidergic mechanism is involved in the antinociceptive action of khat probably associated with A $\delta$ fibers.

Pretreatment of mice with bicuculline attenuated the antinociceptive effect of khat extract in hot plate and tail-flick tests. Reports about the involvement of GABA in khat analgesia are rare. One study reported that prolonged khat administration resulted in excessive release followed by decreased GABA concentration in different brain areas (38). Since bicuculline is a competitive antagonist of $\mathrm{GABA}_{\mathrm{A}}$ receptor, the behavioral effects of khat extract following bicuculline administration can only be due to reversal of GABA-mediated analgesia. Thus, it could be speculated that the acute khat consumption adopted in our study increased GABA level in brain as previously detected in the early phase of chronic khat habituation (39). Therefore, the $\mathrm{GABA}_{\mathrm{A}}$ antagonist, bicuculline, attenuated the antinociceptive action of khat extract in hot plate and tail-flick tests.

Interestingly, haloperidol, the $\mathrm{D}_{2}$-receptor antagonist, reversed the antinociceptive effect of khat extract in the tail-flick test and the first phase of formalin test, but not the hot plate test, second phase of the formalin test, and acetic acid test. As reported earlier, haloperidol did not inhibit cathinone analgesia in acetic acid-induced writhing (33). Cathinone increased the release of dopamine from presynaptic sites and increased extracellular dopamine concentration $(40,41)$. Both hot plate and tail-flick tests are thermic stimuli involving stimulation of A $\delta$ fibers; yet, they follow different neural pathways. The tail flick is a spinal reflex, whereas the hot plate response is under supraspinal control $(36,37,42,43)$. It is a reasonable question to query whether the antagonistic effect of haloperidol on khat analgesia in the tail-flick test is mediated spinally through the dopaminergic pathway and not supraspinally as in the hot plate test. Since our results indicated that khat abolished all types of painful sensations, the analgesic effect produced by systemically administered khat occurs because of the potentiated interaction that exists between spinal and supraspinal effects achieved simultaneously suggesting a cross-talk between the two pathways. Thus, the results in our hand only excludes a specific role of dopamine in mediating the effect of khat extract on pain signals induced in hot plate test or those initiated via stimulation of $\mathrm{C}$ fibers following acetic acid and formalin administration.

One may argue that the results of antinociceptive action of khat could be attributed to the sedative action or the effect of the khat extract on the locomotor activity. In fact, cathinone administration in rats $(44,45)$ and mice (46) markedly increased spontaneous locomotor activity almost comparable with amphetamine (47). Similar increases in locomotor activity were observed after acute and subchronic oral administration of $C$. edulis leaves or cathinone in rats $(48,49)$. Moreover, both antinociception and locomotion are mediated via different pathways. Reports indicated that the potent antinociceptive action of morphine is associated with increased locomotor activity in mice (50). This confirms that the observed antinociceptive action of khat extract in the pain tests is not attributed to the effect on motor activity.

Our results indicated that the muscarinic antagonist atropine and the selective $\alpha_{1}$ blocker prazosin did not modify the analgesic effect of khat extract. This is the first study to address 
whether cholinergic or $\alpha 1$ receptors are involved in khat analgesia. Agonists of cholinergic and adrenergic systems are targets for the treatment of pain (51). Previous studies have shown that the non-selective $\alpha$ blocker phenoxybenzamine reversed cathinone-induced analgesia (33). The vasoconstrictor effect of khat on coronary vessels was independent of $\alpha_{1}$ adrenergic receptor stimulation (52). In a randomized clinical study, it was found that the $\alpha_{1}$ receptors are not involved in mediating the cardiovascular effects of khat in humans (53). Therefore, the present results allow the suggestion that the analgesic effect of khat is not mediated by direct stimulation of $\alpha_{1}$ receptors and most probably through mechanisms involving noradrenaline release and stimulation of $\alpha_{2}$ receptors. This warrants further studies using selective $\alpha_{2}$ antagonists.

Newly synthesized muscarinic agonists are proved to be analgesic both in vitro and in vivo (54). Similarly, the inability of atropine to antagonize the antinociceptive action of khat extract on tested pain signals excluded a direct interaction of khat extract with muscarinic receptors. It is reported that the anticholinesterase compound physostigmine attenuated the painful stimuli in formalin test (55). Khat extract was found to inhibit acetylcholinesterase enzyme in khat-chewing individuals (56). Recently, amphetamine and its derivatives are reported to inhibit acetylcholinesterase activity in rats $(57,58)$. If khat analgesia followed the same scenario, it is conceivable that khat by inhibiting cholinesterase enzyme produced accumulation of acetylcholine, which exerts an antinociceptive action. This explains why the cholinergic antagonist atropine that act on the receptor level did not antagonize the antinociceptive action of khat. Neuronal nicotinic receptors also showed analgesic effects in experimental and clinical trials (59). Whether the antinociceptive effect of khat is mediated through the activation of nicotinic receptors caused by accumulated acetylcholine needs further investigations.

\section{REFERENCES}

1. Johannes CB, Le TK, Zhou X, Johnston JA, Dworkin RH. The prevalence of chronic pain in United States adults: results of an internet-based survey. J Pain (2010) 11(11):1230-9. doi:10.1016/j.jpain.2010.07.002

2. Christie MJ. Cellular neuroadaptations to chronic opioids: tolerance, withdrawal and addiction. Br J Pharmacol (2008) 154(2):384-96. doi:10.1038/ bjp. 2008.100

3. Soeken KL, Miller SA, Ernst E. Herbal medicines for the treatment of rheumatoid arthritis: a systematic review. Rheumatology (2003) 42(5):652-9. doi:10.1093/rheumatology/keg183

4. Mossie A, Kebedez S, Gobena T. Association between khat chewing and intestinal parasitic infestations: a community based, cross-sectional study done in Jimma Town, Southwest Ethiopia. Ethiop Med J (2013) 51:187-95.

5. Patel NB. Mechanism of action of cathinone: the active ingredient of khat (Catha edulis). East Afr Med J (2000) 77:329-32.

6. Kebede D, Alem A, Mitike G, Enquselassie F, Berhane F, Abebe Y, et al. Khat and alcohol use and risky sex behaviour among in-school and out-of-school youth in Ethiopia. BMC Public Health (2005) 5:109. doi:10.1186/1471-2458-5-109

7. Hoffman R, Al'Absi M. Khat use and neurobehavioral functions: suggestions for future studies. J Ethnopharmacol (2010) 132:554-63. doi:10.1016/j. jep.2010.05.033

8. Kalix P. Khat, an amphetamine-like stimulant. J Psychoactive Drugs (1994) 26(1):69-74. doi:10.1080/02791072.1994.10472604

\section{CONCLUSION}

Khat extract proved to be analgesic against thermic and chemical noxious stimuli in different pain models. The opioidergic and dopaminergic pathways are involved in the antinociceptive action of khat probably by stimulating A $\delta$ fibers. The analgesic effect of khat is also mediated $v i a \mathrm{GABA}_{\mathrm{A}}$ receptors. The antinociceptive action of khat is not involving direct interaction with $\alpha_{1}$ receptors or the muscarinic cholinergic receptors. Further pharmacological techniques such as binding studies and electrophysiological procedures may be useful to fully elucidate the antinociceptive effects of khat extract.

\section{AUTHOR CONTRIBUTIONS}

EA put research design, performed data analysis, and writing of the manuscript. HA, AA, and LK shared the idea, experimental design, and manuscript preparation. HA conducted experiments and participated in data analysis and manuscript preparation. All the authors have read and approved the final manuscript for publication.

\section{ACKNOWLEDGMENTS}

The authors thank Dr. Siddiq A. Ibrahim, Substance Abuse Research Center, Jazan University, Jazan, Saudi Arabia, for the supply of the Catha edulis leaves. We also thank Dr. Lamiaa A. Shaala, Natural Products Unit, King Fahd Medical Research Center, King Abdulaziz University, Jeddah, Kingdom of Saudi Arabia, for identifying the plant species and for preparing the khat extract. This work was supported by the fund from King Abdulaziz City for Science and Technology (Grant No. A-S-35426). This financial support for the project enabled the provision of requirements and necessary chemical substances for the research.

9. Zyoud SH. Bibliometric analysis on global Catha edulis (khat) research production during the period of 1952-2014. Zyoud Globalization Health (2015) 11:39. doi:10.1186/s12992-015-0124-x

10. Nutt D, King LA, Saulsbury W, Blakemore C. Development of a rational scale to assess the harm of drugs of potential misuse. Lancet (2007) 369(9566):1047-53. doi:10.1016/S0140-6736(07)60464-4

11. Feyissa AM, Kelly JP. A review of the neuropharmacological properties of khat. Prog Neuropsychopharmacol Biol Psychiatry (2008) 32:1147-66. doi:10.1016/j.pnpbp.2007.12.033

12. WHO. WHO Expert Committee on Drug Dependence. (Vol. 942). Geneva: World Health Organization (2006). p. 1-21.

13. Al-Habori M, Al-Mamary M. Long-term feeding effects of Catha edulis leaves on blood constituents in animals. Phytomedicine (2004) 11(7):639-44. doi:10.1016/j.phymed.2003.06.004

14. Murdoch C, Aziz HA, Fang HY, Jezan H, Musaid R, Muthana M. Khat (Catha edulis) alters the phenotype and anti-microbial activity of peripheral blood mononuclear cells. J Ethnopharmacol (2011) 138(3):780-7. doi:10.1016/j. jep.2011.10.030

15. Nencini P, Abdullahi MA, Anania MC, Moscucci M, Paroli E. Prolonged analgesia induced by cathinone. The role of stress and opioid and nonopioid mechanisms. Pharmacology (1984) 29:269-81. doi:10.1159/ 000138023

16. Nencini P, Ahmed AM. Naloxone-reversible antinociceptive activity of cathinone, the active principle of khat, in the mouse and rat. Pharmacol Res Commun (1982) 14:759-70. doi:10.1016/S0031-6989(82)80082-9 
17. Connor J, Makonnen E, Rostom A. Comparison of analgesic effects of khat (Catha edulis Forsk.) extract, D-amphetamine and ibuprofen in mice. J Pharm Pharmacol (2000) 52:107-10. doi:10.1211/0022357001773580

18. Clarke PB, Franklin KB. Infusion of 6-hydroxydopamine into nucleus accumbens abolish the analgesic effect of amphetamine but not of MOR in the formalin test. Brain Res (1992) 580:106-10. doi:10.1016/0006-8993(92) 90932-Y

19. Świeboda P, Filip R, Prystupa A, Drozd M. Assessment of pain: types, mechanism and treatment. Ann Agric Environ Med (2013) 1:2-7.

20. Dickenson A, Sullivan A. Peripheral origins and central modulation of subcutaneous formalin-induced activity of rat dorsal horn neurons. Neurosci Lett (1987) 83:207-11. doi:10.1016/0304-3940(87)90242-4

21. Grichnik K, Ferrante F. The difference between acute and chronic pain. $M t$ Sinai J Med (1991) 58:217-20.

22. Afify E, Khedr M, Omar A, Nasser S. The involvement of K(ATP) channels in morphine-induced antinociception and hepatic oxidative stress in acute and inflammatory pain in rats. Fundam Clin Pharmacol (2013) 27:623-31. doi: $10.1111 /$ fcp. 12004

23. Hemnani TJ, Khan IM, Patki VP, Dashputra PG. Effect of diphenyl-hydantoin with diazepam on electoseizure and chemoseizure susceptibility in mice. Indian J Med Res (1983) 77:521-4.

24. Aziz HA, Peh KK, Tan YT. Extraction and microencapsulation of khat: effects on sexual motivation and estradiol level in female rats. J Sex Med (2009) 6:682-95. doi:10.1111/j.1743-6109.2008.01157.x

25. Nyongesa AW, Patel NB, Onyango DW, Odongo HO, Wango EO. Khat (Catha edulis) lowers plasma luteinizing hormone (LH) and testosterone secretion, but increases cortisol levels in male rabbits. J Ethnopharmacol (2008) 116:245-50. doi:10.1016/j.jep.2007.11.022

26. Kimani ST, Nyongesa AW. Effects of single daily khat (Catha edulis) extract on spatial learning and memory in CBA mice. Behav Brain Res (2008) 195:192-7. doi:10.1016/j.bbr.2008.05.022

27. Koster R, Anderson M, De Beer EJ. Acetic acid for analgesic screening. Fed Proc (1959) 18:412-6.

28. Hunskaar S, Hole K. The formalin test in mice: dissociation between inflammatory and non-inflammatory pain. Pain (1987) 30:103-14. doi:10.1016/0304-3959(87)90088-1

29. Woolfe G, MacDonald AD. The evaluation of the analgesic action of pethidine hydrochloride. J Pharmacol Exp Ther (1944) 80:300-7.

30. D'Amour FE, Smith DL. A method for determining loss of pain sensation. J Pharmacol Exp Ther (1941) 72:174-9.

31. Abdulwaheb M, Makonnen E, Debella A, Abebe D. Effect of Catha edulis foresk (khat) extracts on male rat sexual behaviour. J Ethnopharmacol (2007) 110:250-6. doi:10.1016/j.jep.2006.09.019

32. Omar AS. Modulation of visceral nociception, inflammation and gastric mucosal injury by cinnarazine. Drug Target Insights (2007) 2:29-38.

33. Della Bella D, Carenzi A, Frigeni V, Reggiani A, Zambon A. Involvement of monoaminergic and peptidergic components in cathinone-induced analgesia. Eur J Pharmacol (1985) 114:231-4. doi:10.1016/0014-2999(85) 90633-8

34. Nencini P, Fraioli S, Pascucci T, Nucerito CV. (-)-Norpseudoephedrine, a metabolite of cathinone with amphetamine-like stimulus properties, enhances the analgesic and rate decreasing effects of morphine, but inhibits its discriminative properties. Behav Brain Res (1998) 92:11-20. doi:10.1016/ S0166-4328(97)00123-X

35. Lu Y, Sweitzer SM, Laurito CE, Yeomans DC. Differential opioid inhibition of C- and A delta- fiber mediated thermonociception after stimulation of the nucleus raphe magnus. Anesth Analg (2004) 98(2):414-9. doi:10.1213/01. ANE.0000094334.12027.06

36. Chung KM, Song DK, Huh SO, Kim YH, Cho MR, Suh HW. Supraspinal NMDA and non-NMDA receptors are differentially involved in the production of antinociception by morphine and beta-endorphin administered intracerebroventricularly in the formalin pain model. Neuropeptides (2000) 34:158-66. doi:10.1054/npep.2000.0805

37. Damaj M. Behavioral modulation of neuronal calcium/calmodulindependent protein kinase II activity: differential effects on nicotine-induced spinal and supraspinal antinociception in mice. Biochem Pharmacol (2007) 74:1247-52. doi:10.1016/j.bcp.2007.07.008

38. Al-Awdi S, Al-Kadi H, Shehab M. Effect of khat-habituation on GABA level in brain. Asian J Pharm Life Sci (2013) 3:74-80.
39. Rodríguez-Landa JF, García-Ríos RI, Cueto-Escobedo J, Bernal-Morales B, Contreras CM. Participation of GABAA chloride channels in the anxiolytic-like effects of a fatty acid mixture. Biomed Res Int (2013) 2013:121794. doi:10.1155/2013/121794

40. Schechter MD. Rats become acutely tolerant to cathine after amphetamine or cathinone administration. Psychopharmacology (1990) 101:126-31. doi:10.1007/BF02253729

41. Schechter MD. Dopaminergic nature of acute cathine tolerance. Pharmacol Biochem Behav (1990) 36:817-20. doi:10.1016/0091-3057(90)90083-T

42. Svokos K, Nalwalk JW, Leurs R, Menge WM, Timmerman HH, Hough H. A role for spinal, but not supraspinal, alpha(2) adrenergic receptors in the actions of improgan, a powerful, non-opioid analgesic. Brain Res (2001) 923:12-9.

43. Wang QA, Cao JL, Zeng YM, Ti-jun DA. GABAA receptor partially mediated propofol-induced hyperalgesia at superspinal level and analgesia at spinal cord level in rats. Acta Pharmacol Sin (2004) 12:1619-25.

44. Kalix P. Hypermotility of the amphetamine type induced by a constituent of khat leaves. Br J Pharmacol (1980) 68:11-3. doi:10.1111/j.1476-5381.1980. tb10690.x

45. Banjaw MY, Mayerhofer A, Schmidt WJ. Anticataleptic activity of cathinone and MDMA (Ecstasy) upon acute and subchronic administration in rat. Synapse (2003) 49:232-8. doi:10.1002/syn.10236

46. Zelger JL, Carlini EA. Anorexigenic effects of two amines obtained from Catha edulis forsk. (Khat) in rats. Pharmacol Biochem Behav (1980) 12:701-5. doi:10.1016/0091-3057(80)90152-5

47. Kalix P. Pharmacological properties of the stimulant khat. Pharmacol Ther (1990) 48:397-416. doi:10.1016/0163-7258(90)90057-9

48. Banjaw MY, Schmidt WJ. Behavioural sensitisation following repeated intermittent oral administration of Catha edulis in rats. Behav Brain Res (2005) 156:181-9. doi:10.1016/j.bbr.2004.05.020

49. Banjaw MY, Miczek K, Schmidt WJ. Repeated Catha edulis oral administration enhances the baseline aggressive behavior in isolated rats. J Neural Transm (2006) 113:543-56. doi:10.1007/s00702-005-0356-7

50. Murphy N, Lam H, Maidment N. A comparison of morphine-induced locomotor activity and mesolimbic dopamine release in C57BL6, 129Sv and DBA2 mice. J Neurochem (2001) 79:626-35. doi:10.1046/j.1471-4159. 2001.00599.x

51. Pan HL, Wu ZZ, Zhou HY, Chen SR, Zhang HM, Li DP. Modulation of pain transmission by G-protein-coupled receptors. Pharmacol Ther (2008) 117:141-61. doi:10.1016/j.pharmthera.2007.09.003

52. Al-Hashem FH, Dallak MA, Nwoye LO, Bin-Jaliah IM, Al-Amri HS, Rezk MH, et al. Acute exposure to Catha edulis depresses contractility and induces myocardial infarction in spontaneously contracting, isolated rabbit's heart. Saudi J Biol Sci (2012) 19:93-101. doi:10.1016/j.sjbs.2011. 01.002

53. Hassan NA, Gunaid AA, El-Khally FM, Al-Noami MY, Murray-Lyon IM. Khat chewing and arterial blood pressure. A randomized controlled clinical trial of alpha-1 and selective beta-1 adrenoceptor blockade. Saudi Med J (2005) 2:537-41.

54. Matera C, Flammini L, Quadri M, Vivo V, Ballabeni V, Holzgrabe U, et al. Bis(ammonio) alkane-type agonists of muscarinic acetylcholine receptors: synthesis, in vitro functional characterization, and in vivo evaluation of their analgesic activity. Eur J Med Chem (2014) 75:222-32. doi:10.1016/j. ejmech.2014.01.032

55. Mojtahedin A, Tamaddonfard E, Zanbouri A. Role of central muscarinic cholinergic receptors in the formalin-induced pain in rats. Indian J Pharmacol (2009) 41:144-7. doi:10.4103/0253-7613.55205

56. Al-Akwa A, Shaher M, Al-Akwa S, Aleryani S. Free radicals are present in human serum of Catha edulis forsk (Khat) abusers. J Ethnopharmacol (2009) 125:471-3. doi:10.1016/j.jep.2009.07.012

57. Rezin GT, Scaini G, Ferreira GK, Cardoso MR, Gonçalves CL, Constantino LS, et al. Inhibition of acetylcholinesterase activity in brain and behavioral analysis in adult rats after chronic administration of fenproporex. Metab Brain Dis (2012) 27:453-8. doi:10.1007/s11011-0129331-9

58. Varela RB, Valvassori SS, Lopes-Borges J, Fraga DB, Resende WR, Arent $\mathrm{CO}$, et al. Evaluation of acetylcholinesterase in an animal model of mania induced by D-amphetamine. Psychiatry Res (2013) 209:229-34. doi:10.1016/j. psychres.2012.11.021 
59. Umana IC, Daniele CA, McGehee DS. Neuronal nicotinic receptors as analgesic targets: it's a winding road. Biochem Pharmacol (2013) 86:1208-14. doi:10.1016/j.bcp.2013.08.001

Conflict of Interest Statement: The authors declare that the research was conducted in the absence of any commercial or financial relationships that could be construed as a potential conflict of interest.
Copyright (c) 2017 Afify, Alkreathy, Ali, Alfaifi and Khan. This is an open-access article distributed under the terms of the Creative Commons Attribution License (CC BY). The use, distribution or reproduction in other forums is permitted, provided the original author(s) or licensor are credited and that the original publication in this journal is cited, in accordance with accepted academic practice. No use, distribution or reproduction is permitted which does not comply with these terms 